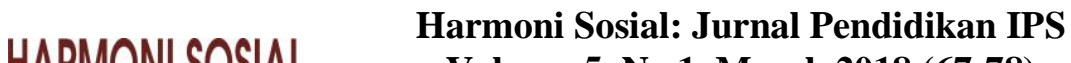 \\ Volume 5, No 1, March 2018 (67-78)
}

\section{PENGARUH KREATIVITAS MENGAJAR GURU, POLA ASUH ORANG TUA, DAN IKLIM SEKOLAH TERHADAP PRESTASI BELAJAR SISWA}

\author{
Pius Herman Tuwa ${ }^{1} *$, Nahiyah Jaidi Faraz ${ }^{2}$ \\ ${ }^{1}$ STKIP St. Paulus Ruteng \\ ${ }^{2}$ Universitas Negeri Yogyakarta \\ Jl Ahmad Yani 10 Manggarai NTT Tenda, Watu, Ruteng, Manggarai, NTT. 86511, Indonesia \\ ${ }^{2}$ Jl. Colombo No. 1, Depok, Sleman 55281, Yogyakarta, Indonesia \\ * Corresponding Author. Email: herytuwa@gmail.com
}

\begin{abstract}
Abstrak
Penelitian ini merupakan penelitian asosiatif kausal dengan pendekatan kuantitatif. Populasi penelitian ini adalah semua siswa kelas XI IPS di 13 SMA swasta di Kabupaten Gunungkidul. Sampel sekolah sejumlah lima sekolah diambil dengan teknik cluster random sampling. Sampel siswa sebanyak 97 siswa ditentukan dengan teknik area proporsional random sampling. Pengumpulan data menggunakan angket untuk variable kreativitas mengajar guru, pola asuh orang tua, iklim sekolah, serta dokumentasi untuk variable Prestasi belajar. Pengujian validitas instrument dilakukan dengan expert judgment dan confirmatory factor analysis, sedangkan uji reliabilitas menggunakan Alfa Cronbach. Analisis data menggunakan teknik regresi linier sederhana dan ganda, dengan taraf signifikansi 0,05. Hasil penelitian menunjukkan bahwa: (1) kreativitas mengajar guru berpengaruh positif dan signifikan terhadap prestasi belajar siswa, dan kreativitas mengajar guru termasuk kategori tinggi; (2) pola asuh orang tua berpengaruh positif dan signifikan terhadap prestasi belajar siswa, dan pola asuh orang tua termasuk kategori sedang; (3) iklim sekolah berpengaruh positif dan signifikan terhadap prestasi belajar siswa, dan iklim sekolah termasuk kategori tingggi; (4) kreativitas mengajar guru, pola asuh orang tua, iklim sekolah secara bersama-sama berpengaruh positif dan signifikan terhadap hasil belajar siswa. Hal ini berarti kreativitas mengajar guru, motivasi belajar, dan lingkungan keluarga berpengaruh terhadap prestasi belajar siswa secara terpisah maupun secara bersama-sama.
\end{abstract}

Kata kunci: kreativitas mengajar guru, pola asuh orang tua, iklim sekolah

\section{THE EFFECT OF TEACHERS' CREATIVITY, PARENTING, AND SCHOOL ATMOSPHERE ON STUDENTS LEARNING ACHIEVEMENT ABSTRACT}

This study is an associativecausal research using quantitative approach. The population was all XI IPS students in 13 private senior high schools at Gunungkidul regency. Then, 5 schools weretaken to be the sample by using cluster random sampling. Whereas, the sample of the students were 97 students determined by using the technique of area proportional random sampling. The technique of data collection for the variable of teachers' creativity, parenting, and school climate was questionnaire, while documentation was used to collect data for the variable of learning achievement. The validity testing of instruments of this research was expert judgment and confirmatory factor analysis and alpha cronbach is taken for reliability testing. The data were analyzed by using simple and multiple regression technique at 0.05 of significance level. The findings of the study show that: (1) the teachers' creativity has positive and significant effect on the students' learning achievement, and this is included in high category; (2) parenting has positive and significant effect on the students' learning achievement, and this is included in middle category; (3) school climate has positive and significant effect to the students' learning achievement, and this is also in high category; (4) teachers' creativity, parenting, and school climate simultaneously have positive and significant effect on the students' learning achievement. It is concluded that, either separately or simultaneously, teachers' creativity, learning motivation, and family have an effect on students' learning achievement.

Keywords: teachers' creativity, parenting, school climate 


\section{Pendahuluan}

Pembangunan nasional dewasa ini sedang giat-giatnya dilaksanakan oleh pemerintah bersama seluruh rakyat Indonesia yang bertujuan mewujudkan masyarakat adil dan makmur baik material maupun spiritual berdasarkan Pancasila di dalam wadah Negara Kesatuan Republik Indonesia yang merdeka, bersatu, berdaulat adil dan makmur dan berkedaulatan rakyat dalam suasana peri kehidupan bangsa yang aman, tentram, tertib, dinamis, dalam lingkungan yang merdeka, bersahabat, tertib dan damai. Di dalam operasionalnya tujuan pembangunan nasional yang termaksud dalam Pembukaan Undang Undang Dasar 1945 salah satunya adalah upaya pemerintah dalam usaha mencerdaskan kehidupan bangsa. Mencerdaskan kehidupan bangsa merupakan tugas dan tanggung jawab dari dunia pendidikan yang terdiri atas keluarga, sekolah, dan masyarakat, ini berarti pendidikan mempunyai potensi yang sangat strategi dan menentukan dalam menghadapi tantangan pembangunan nasional yang menentukan pelaku-pelaku pembangunan yang berkualitas dan handal dalam penguasaan ilmu pengetahuan dan teknologi. Untuk meningkatkan kualitas manusia sebagai sumber daya insani, dunia pendidikan yang dipegang oleh Pemerintahan melalui Dinas Pendidikan Nasional menjadi ujung tombak untuk memenuhi harapan itu secara nyata, atas dasar ini pendidikan kita harus benar-benar semakin diarahkan pada usaha untuk meningkatkan kualitas sumber daya manusia. Hal ini harus disadari secara bersungguh-sungguh, karena manusia merupakan kekuatan utama dari pembangunan.

Pendidikan mempunyai peran strategis sebagai sarana human resources dan human investment. Hal ini dapat diartikan bahwa pendidikan selain bertujuan menumbuh kembangkan kehidupan yang lebih baik, juga telah ikut mewarnai dan menjadi landasan moral dan etika dalam proses pemberdayaan jati diri bangsa. Oleh karenanya, pendidikan dapat menjadi bagian dari proses humanisasi. Sebagai proses humanisasi, pengembangan aspek kemanusiaan manusia menjadi fokus perhatian pendidikan sebagai elemen yang berpotensi positif dalam pembangunan kehidupan yang beradab. Atas pertimbangan mendasar inilah maka pendidikan dapat dimaknai sebagai tindakan sadar dengan tujuan memelihara dan mengembangakan kesucian dan potensi insani menuju terbentuknya manusia yang utuh. Ditegaskan juga bahwa pendidikan dan aksiaksi budaya yang membebaskan bukanlah proses transformasi yang mengasingkan ilmu pengetahuan, namun merupakan proses yang autentik untuk mencari ilmu pengetahuan guna memenuhi hasrat keinginan siswa dan guru dengan kesadaran untuk menciptakan pengetahuan baru.

Meskipun demikian tak dapat dipungkiri bahwa masih banyak tantangan yang harus dihadapi dunia pendidikan dewasa ini. Pada skala nasional, salah satu tuntutan dan tantangan yang dihadapi dunia pendidikan pada saat ini dan ke depan adalah pendidikan yang dapat menghasilkan sumber daya manusia yang memiliki kompetensi yang utuh, yaitu kompetensi sikap; kompetensi pengetahuan; dan kompetensi keterampilan yang terintegrasi. Selain itu, menjawabi tuntutan era informasi dan teknologi, setiap pribadi dituntut untuk menguasai IPTEK secara optimal.Ini berarti, sumber daya manusia tersebut harus mempunyai mutu yang tinggi dan memiliki kemampuan komparatif, inovatif, kompetitif, berpikir kritis dan mampu berkolaboratif sehingga lebih mudah menyerap informasi baru, mempunyai kemampuan yang handal dalam beradaptasi untuk menghadapi perubahan zaman yang semakin cepat, serta lebih dapat menyelesaikan masalah dengan mudah.Namun demikian, tidak dapat dipungkiri bahwa hal ini masih merupakan cita-cita besar bangsa Indonesia yang belum tercapai sepenuhnya.

Dalam rangka ini Pemerintah kita membuat Undang-Undang Sistem Pendidikan Nasional, melalui pendidikan nasional itu diusahakan lahirnya manusia Pancasila sebagai manusia pembangunan yang tinggi kualitasnya dan mampu mandiri serta mampu mengembangkan masyarakat, bangsa dan Negara Indonesia. Bertitik tolak dari kesadaran itu maka perlu direncanakan langkahh kebijaksanaan dan program untuk menciptakan kualitas manusia yang dibutuhkan sesuai dengan tuntutan zaman. Dalam rangka ini semua aspek masyarakat harus berperan serta dalam peningkatan pendidikan bangsa. Tujuan pendidikan nasional Bangsa Indonesia yang tercantum dalam pasal 3 UU RI No 20 tahun 2003 (Presiden Republik Indonesia, 2003).

Undang-undang No 14 tahun 2005 tentang Guru dan Dosen (Presiden Republik Indonesia, 2005) menyebutkan bahwa guru 
dan dosen harus menguasai empat kompetensi yaitu kompetensi pedagogik, kompetensi kepribadian, kompetensi sosial, dan kompetensi profesional. Kompetensi pedagogik adalah kemampuan guru dan dosen mengelolah proses pembelajaran. Seorang guru yang mempunyai kompetensi pedagogik minimal telah menguasai bidang studi tertentu, ilmu pendidikan, baik metode pembelajaran, maupun pendekatan pembelajaran. Kompetensi kepribadian adalah kemampuan kepribadian guru dan dosen yang mantap, berakhlak mulia, berwibawa, dan menjadi teladan bagi peserta didiknya. Kompetensi social adalah kemampuan seseorang guru dan dosen untuk berkomunikasi dan berinteraksi secara efektif dan efisien dengan peserta didik, guru, orang tua, dan masyarakat sekitar. Kompetensi professional adalah kemampuan penguasaan materi pembelajaran secara luas dan men-dalam yang memungkinkan untuk membimbing peserta didik memenuhi standar kompetensi yang ditetapkan dalam standar nasional.

Sehubungan dengan kompetensi pedagogik guru, paling tidak terdapat dua hal yang perlu mendapat perhatian serius terhadap pendekatan yang masih banyak digunakan di kelas-kelas saat ini. Pertama, pendekatan pembelajaran yang berpusat kepada guru (teacher oriented) sudah kurang tepat dipakai karena memiliki banyak kelemahan, antara lain: mudah menumbuhkan rasa bosan pada diri peserta didik yang pada gilirannya menurunkan motivasi belajar, mengakibatkan kurang perhatian dan menurunnya konsentrasi belajar.

Potensi preserta didik dapat dikembangkan melalui aktivitas belajar di sekolah, sehingga apa yang menjadi tujuan belajar tersebut dapat tercapai yang terwujud dalam suatu prestasi belajar. Prestasi belajar sangat penting sebagai indikator keberhasilan baik bagi seorang pendididik maupun bagi pserta didik, bagi seorang pendidik, prestasi belajar dapat dijadikan sebagai pedoman penilaian terhadap keberhasilan dalam kegiatan pembelajaran peserta didik. Bagi peserta didik, prestasi belajar merupakan informasi yang berfungsi utuk mengukur tingkat kemampuan atau keberhasilan belajarnya, apakah mengalami perubahan yang yang bersifat positif maupun yang bersifat negatif.

Pencapaian prestasi belajar khususnya menyangkut ranah afektif dan psikomotor relative sulit diukur karena informasi yang disampaikan pada umumnya lebih banyak me- nyentuh ranah kognitif. Konsekuensi lebih lanjut adalah munculnya iklim sekolah yang cenderung bersifat otoriter. Iklim yang tidak demokratis ini menyebabkan proses pembelajaran menjadi kaku dan menimbulkan efek destruktif terhadap aspek-aspek rasa ingin tahu, kepercayaan diri, kreativitas, kemerdekaan berpikir, dan harga diri dikalangan peserta didik. Dengan demikian pendekatan ini telah gagal mengantarkan siswa memiliki keterampilan yang harus mereka peroleh untuk dapat hidup layak dalam dunia nyata dikemudian hari karena sumber daya manusia yang mereka miliki tidak mampu memenuhi kebutuhan masyarakat. Kedua, kekeliruan dalam memahami sistem kerja otak telah mendorong penentu kebijakan memilih pendekatan pembelajaran yang kurang tepat. Proses pembelajaran berpijak pada asumsi yang menganggap bahwa intelegensi merupakan cirri bawaan yang bersifat statis, tidak berhubungan dengan emosi, dan hanya terdiri dari kemampuan numerik dan lingual semata, telah mengabaikan kemampuan (bakat) yang dapat memperkaya dan memajukan kedipan dalam merespon lingkungan secara efektif. Akibatnya, lulusan tidak memiliki kemampuan dan fleksibilitas untuk menyesuaikan diri dengan tuntutan pembangunan. Kejadian-kejadian pahit yang telah dan sedang dialami oleh bangsa ini merupakan isyrat bagi para pendidik untuk lebih cermat dan serius dalam mengkaji hasil-hasil penilitian para pakar agar mampu menentukan kebijakan yang tepat khususnya dalam memilih pendekatan yang tepat.

Kenyataan di lapangan menunjukkan bahwa masih banyaknya guru yang dalam melaksanakan tugasnya hanya berlaku sebagai pengajar saja itu pun tanpa persiapan yang layak yang ditunjukan dengan tidak mempersiapkan rancangan pembelajaran, melaksanakan PBM dengan asal memenuhi kewajiban, tidak melihat dan mendiagnosis kesulitan belajar siswa, tidak mempersiapkan evaluasi dan lain sebagainya. Gambaran guru seperti diatas menunjukkan kekurang profesionalannya guru di lapangan, hal ini yang dapat terlihat di lapangan ternyata masih banyak guru yang mengajar tidak sesuai dengan disiplin ilmu yang dimilikinya sehingga ketika PBM berlangsung kedalaman dan keluasan materi serta metoda dan teknik mengajarnya pun tidak sesuai dengan yang seharusnya dilakukan. Dengan kondisi seperti itu maka tidak menutup 
kemungkinan jika hal ini berlangsung terus menerus tanpa ada perubahan dan perkembangan yang berarti tidak menutup kemungkinan para orang tua siswa akan mempersiapkan putra-putrinya untuk belajar diluar daerah mengingat layanan yang diberikan kurang memadai. Hal ini ditunjukkan dengan kurang kreativitas mengajar guru dalam melaksanakan tugas.

Maka dalam hal ini yang perlu di perhatikan adalah kreativitas mengajar guru, untuk mingkatkan prestasi belajar Ekonomi siswa. Winkel (1996, p. 162) mendefinisikan "Prestasi belajar adalah bukti keberhasilan usaha yang dapat dicapai". Prestasi belajar diharapkan dapat mengetahui kemampuan siswa dalam menyerap materi pelajaran dalam periode waktu tertentu yang sedikitnya mencakup tiga aspek yaitu kognitif (pengetahuan), afektif (sikap) dan psikomotorik (ketrampilan atau kecakapan). Dalam pengukuran terhadap prestasi belajar dapat dinyatakan dalam bentuk angka, huruf, ataupun simbol-simbol. Akan tetapi pada kenyataannya usaha untuk mencapai prestasi belajar yang baik bukan proses yang sederhana. Proses belajar yang dicapai setiap siswa tidak sama, ada yang mencapai prestasi tinggi, sedang, rendah. siswa dan guru selalu menginginkan prestasi belajar yang baik atau tinggi, oleh karena itu mereka harus mengetahui bagaimana prestasi belajar yang baik itu diperoleh, bagaimana prosesnya dan apa saja yang mempengaruhi tercapainya prestasi belajar yang optimal.

Dalam proses belajar-mengajar di sekolah, sering dijumpai beberapa masalah, di antaranya yaitu siswa hanya terpaku untuk menghafal teks yang ada di buku tanpa bisa mengembangkan pengetahuannya. Kemudian ketidak mampuan siswa dalam memahami pelajaran yang diberikan oleh guru di sekolah. Hal itu dikarenakan guru dalam mengajar lebih memilih menerapkan metode dan cara mengajar yang cenderung monoton dan membosankan, sehingga menyebabkan siswa kurang termotivasi dan guru kurang mendapat perhatian dari siswa di kelas yang berujung pada dampak prestasi belajar semakin rendah dan tujuan pembelajaran di sekolah tidak tercapai. Dalam kaitan ini, guru harus memiliki pandangan yang lebih luas dan kreativitas yang tinggi.

Kreativitas yang dimaksud yaitu upaya meningkatkan daya pikir atau gagasan seseorang dalam menjalankan aktivitasnya. Me- lalui kreativitas diharapkan pelaksanaan suatu aktivitas lebih bersifat aktif, dinamis, menggairahkan dan pada akhirnya mengarah pada pencapaian kualitas hasil yang diharapkan. Guru selalu menjadi tokoh sentral dalam pembelajaran di sekolah, kedudukan guru dalam kegiatan mengajar sangat membutuhkan pengembangan kreativitas. Kreativitas seorang guru meliputi gagasan/ide dan berperilaku kreatif dalam menjalankan tugasnya. Guru yang kreatif akan membawa suasana belajar yang bergairah dan menyenangkan anak didiknya, sebaliknya apabila proses pembelajaran itu bersifat pasif, monoton, kurang kreatif, dan lain sebagainya akan mempengaruhi prestasi siswa di kelas.

Berdasarkan realita di sekolah, kiranya perlu adanya pengembangan gagasan/ide dan perilaku pembelajaran guru yang kreatif menjadi faktor penting dalam mencapai prestasi belajar Ekonomi pendidikan yang memadai. Kreativitas guru dapat menciptakan pembelajaran yang lebih aktif, dinamis dan tidak monoton, sehingga siswa akan lebih bersemangat dalam mengikuti pelajaran dikelas. Kreativitas guru berhubungan dengan merancang dan mempersiapkan bahan ajar/materi pelajaran, mengelola kelas, menggunakan metode yang variatif, memanfaatkan media pembelajaran, sampai dengan mengembangkan instrumen evaluasi. Prestasi belajarsiswa sangat memerlukan optimalisasi peran guru dan cara mengajar di kelas. Seorang guru dalam proses belajar mengajar bukanlah sekedar menyampaikan materi tetapi juga harus berupaya agar materi pelajaran yang disampaikan menjadi kegiatan yang menyenangkan dan mudah dipahami oleh siswa. Segala tindakan yang dilakukan guna mencapai tujuan belajar, tersusun sebagai strategi pembelajaran. Hendaknya guru dapat mengelola kelas secara efektif dan efisien, antara lain dengan menerapkan cara mengajar, pemilihan metode pembelajaran dan mampu membuat inovasi baru dalam mengajar yang sesuai dengan materi pembelajaran dan kondisi lingkungan sekolah.

Selain kreativitas mengjar guru dalam membantu anak maningkatkan prestasi belajar, pola asuh orang tua harus merangsang pemikiran dan ketrampilan kreatif anak, serta menyediakan sarana dan prasarana untuk mencapai prestasi belajar Ekonomi siswa. Karena pendidikan sesorang dimulai pertama kali dari pendidikan informal yang biasa dilakukan da- 
lam lingkungan keluarga. Dilingkungan keluarga pertama kali anak mendapat pengaruh, karena itu keluarga merupakan lembaga pendidikan tertinggi yang bersifat informaldan kodrat. Pada keluarga anak mendapatkan asuhan dari orang tua menuju perkembangannya. Keluarga sendiri bagi seorang anak merupakan lembaga pendidikan nonformal pertama, dimana mereka hidup, berkembang dan matang. Dari pendidikan keluarga tersebut anak mendapatkan pengalaman, kebiasaan, keterampilan berbagai sikap dan macam-macam ilmu pengetahuan.

Salah satu faktor dalam keluarga yang mempunyai peran penting dalam pembentukan dan perkembangan dan kepribadian adalah praktik pengasuhan anak. Menurut Santrock (2007, p. 163) pengasuhan (parenting) memerlukan sejumlah kemampuan interpersonal dan mempunyai tuntutan emosional yang besar, namun sangat sedikit pendidikan dan pengetahuan tentang tugas ini. Kebanyakan orang tua mempelajari pengasuhan anak dari orang tua mereka sendiri. Sebagian praktik tersebut mereka terima dan sebagian lagi mereka tinggalkan. Suami dan istri (orang tua) munkin saja membawa pandangan yang berbeda, mengenai pengasuhan kedalam keluarga.

Dalam mengasuh anaknya orang tua dipengaruhi oleh banyak hal seperti budaya yang ada di lingkungannya. Disamping itu juga orang tua di warnai oleh sikap-sikap tertntu dalam memelihara, membimbing dan mengarahkan putra putrinya. Sikap tersebut tercermin dalam pola pengasuhan yang berbeda-beda karena setiap prang tua mempunyai pola pengasuhan tertentu. Keluarga adalah koloni terkecil didalam masarakat dan dari keluargalah akan tercipta pribadi-pribadi tertentu yang akan membaur dalam suatu masarakat. Adakalanya orang tua bersikap atau bertindak sebagai patokan, dan menjadi bagian dari kebiasaan bersikap dan bertingkah laku atau bagian dari kepribadiannya. Orang tua menjdi faktor terpenting dalam menanamkan dasar kepribadian tersebut yang turut menentukan corak dan gambaran seseorang setelah dewasa.

Pola asuh orang tua diidentifikasi melalui adanya perhatian dan kehanggatan, yaitu orang tua dalam mengasuh dan menjalin hubungan interpersonal dengan anak disadari adanya perhatian, penghargaan dan kasih sayang, kebebasan berinisiatif, yaitu kesediaan orang tua untuk memberikan kesempatan ke- pada anak untuk menyampaikan dan mengembangkan pendapat ide, pemikiran dengan tetap mempertimbangkan hak-hak orang lain, nilai dan norma yang berlaku; Kontrol terarah, yaitu pola pengawasan dan pengendalian orang tua dengan cara memberikan bimbingan, arahan dan pengawasan terhadap sikap dan perilaku anak; Pemberian tanggung jawab, yaitu kesediaan orang tua memberikan peran dan tanggung jawab kepada anak atas segala sesuatu yang dilakukan.

Selain kreativitas mengajar guru, dan pola asuh orang tua, prestasi belajar Ekonomi siswa juga dipengaruhi oleh iklim sekolah. Iklim sekolah. Iklim sekolah merupakan lingkungan belajar yang medorong prilaku positif dan kepribadian sama sehingga menciptakan proses belajar mengajar yang optimal. Menurut Larsen (1987) (Moedjiarto, 2002, p. 28) dijelaskan bahwa iklim sekolah merupakan suatu norma, harapan dan kepercayaan dari personilpersonil yang terlibat dalam organisasi sekolah yang dapat memberikan dorongan untuk bertindak guna pencapaian prestasi siswa yang tinggi.

Iklim sekolah yang tidak kondusif akan berdampak negatif terhadap proses pembelajaran dan sulitnya tercapai tujuan pembelajaran, peserta didik akan merasa gelisah, resah, bosan, dan jenuh. Sebaliknya, iklim belajar yang kondusif dan menarik dapat dengan mudah tercapainya tujuan pembelajaran, dan proses pembelajaran yang dilakukan menyenangkan bagi peserta didik. Keseluruhan iklim sekolah dapat ditingkatkan oleh sikap dan perilaku positif dari para siswa dan guru. Iklim sekolah berkaitan dengan lingkungan yang produktif dan kondusif untuk belajar siswa dengan suasana yang mengutamakan kerjasama, kepercayaan, kesetiaan, keterbukaan, bangga, dan komitmen.

Iklim sekolah menengah yang optimal adalah iklim sekolah yang responsif terhadap perkembangan kebutuhan setiap siswa, merangsang pertumbuhan pribadi dan akademik. Iklim sekolah dapat menjadi pengaruh positif pada kesehatan lingkungan belajar atau hambatan yang signifikan untuk belajar. Iklim sekolah yang positif berkaitan dengan peningkatan kepuasan kerja bagi personil sekolah baik guru maupun siswa, menyediakan suasana sekolah yang sehat dan positif. Iklim sekolah yang kurang nyaman akan berdampak terutama pada guru dan siswa. Guru akan menjadi 
kurang semangat untuk datang memberikan pelajaran, begitupun dengan siswa. Oleh sebab itu, harus diciptakan iklim sekolah yang dapat mendukung proses belajar mengajar. Sehingga proses belajar mengajar berjalan dengan optimal.

Berdasarkan masalah yang telah dikemukakan tersebut terdapat beberapa permasalahan yang ditemukan sebagai berikut: guru kurang kreatif dalam proses pembelajaran, guru selalu menggunakan metode mengajar yang konfensional sehingga berpengaruh terhadap prestasi belajar siswa, rendahnya perhatian orang tua terhadap prestasi belajar siswa, rendahnya tingkat pedidikan orang tua, rendahnya pola asuh orang tua terhadap pendidikan siswa, kondisi bangunan fisik sekolah yang tidak memadai, sarana dan prasarana sekolah yang tidak memadai, iklim sekolah yang tiddak mendukung, dan rendahnya prestasi belajar siswa pada mata pelajaran Ekonomi

Tujuan dari penelitian ini untuk mengetahui pengaruh kreativitas mengajar guru dengan prestasi belajar Ekonomi, penaruh pola asuh orang tua dengan prestasi belajar Ekonomi, dan pengaruh iklim sekolah dengan prestasi belajar Ekonomi siswa SMA Swasta di Kabupaten Gunungkidul.

Hasil penelitiana ini diharapkan dapat memberikan sumbangan yang sangat positif bagi berbagai kalangan demi kemajuan ilmu pendidikan. Adapun manfaat yang di maksud adalah manfaat secara teoretis dan manfaat secara praktis. Manfaat teoretis: (a) Memperoleh pengetahuan yang sangat mendalam terkait dengan pengaruh kreativitas mengajar guru, pola asuh orang tua dan iklim sekolah terhadap pretasi belajar siswa, (b) Untuk peneliti lain, agar dapat jadi masukan untuk mengembangkan penelitian yang sejenis, (c) Hasil penelitian ini diharapkan dapat berguna bagi pengembangan ilmu khususnya mengenai kegiatan belajar mengajar untuk meningkatkan kualitas pembelajaran.dan manfaat praktis: diharapkan dapat menjadi referensi bagi para pendidik khususnya guru dalam kegiatan belajar mengajar untuk meningkatkan kreativitas mengajar, kepala sekolah agar dapat mengetahui kekurangannya dan mangembangkan pengetahuannya sehingga dapat menjalankan roda kepemimpinan kepala sekolah dengan baik, dan harapakan dengan penelitian ini, dapat memberikan masukan pada Pemerintah pada umumnya dan Pemerintah Kabupaten Gunung- kidul pada khususnya agar memperhatikan atau memberikan kesempatan kepada guru untuk meningkatkan kreativitasnya guna untuk meningkatkan mutu guru sehingga kinerja guru bisa meningkat dan dapat mewujudkan tujuan pendidikan nasional.

\section{Metode Penelitian}

Penelitian ini tergolong penelitian kuantitatif, karena dalam penelitian ini ingin melihat apakah ada pengaruh antara Kreativitas Mengajar Guru, Pola Asuh Orang Tua, dan Iklim Sekolah terhadap Prestasi Belajar Siswa. Penelitian dengan pendekatan kuantitatif menekankan pada data numerical (angka) yang diolah dengan metode statistik. Pada dasarnya, pendekatan kuantitatif dilakukan pada penelitian inferensial (dalam rangka pengujian hipotesis) dan menyadarkan kesimpulan hasilnya pada suatu probabilitas kesalahan penolakan hipotesis nihil. Jenis penelitian ini adalah penelitian korelasional, karena dalam penelitian ini akan di ketahui pengaruh variabel-variabel bebas kreativitas mengajar guru $\left(\mathrm{X}_{1}\right)$, pola asuh orang tua $\left(\mathrm{X}_{2}\right)$, iklim sekolah $\left(\mathrm{X}_{3}\right)$ dengan variabel terikat prestasi belajar siswa (Y).

Penelitian ini dilaksanakan di SMA Swasta di Kabupaten Gunungkidul dan waktu penelitian dilaksanakan pada bulan Mei dan Juni Tahun ajaran 2016/2017. Populasi dalam penelitian ini adalah adalah seluruh siswa SMA Swasta kelaas IX di Kabupaten Gunungkidul yang berjumlah 13 sekolah swasta dengan jumlah 237 siswa.

Penentuan sampel sekolah dari 13 sekolah swasta dalam penelitian ini diambil 5 sekolah sebagai sampel dengan teknik cluster random sampling maka dari hasil random ditentukanlah sampel pada penelitian ini yaitu: SMA Dominikus wonosari 24 siswa, SMA PGRI Playen 14 siswa, SMA Pembangunan Karangmojo 29 siswa, SMA Muh. Ponjong 36 siswa, dan SMA Muh.Ngawen 25 siswa, dengan jumlah keseluruhan 128 siswa.

Variabel dalam penelitian ini terdiri atas empat variabel, tiga variabel bebas dan satu variabel terikat. Yaitu kreativitas mengajar guru, pola asuh orang tua, dan iklim sekolah sebagai variabel bebasnya sedangkan variabel terikatnya adalah prestasi belajar siswa.

Teknik pengumpulan data dalam penelitian ini adalah survei dengan menggunakan alat pengumpul data berupa angket pene- 
litian. Pengumpulan data tentang kreativitas mengajar guru, pola asuh orang tua, dan iklim sekolah,selanjutnya memberikan kesempatan kepada responden untuk menanyakan hal-hal yang belum dipahami.

Instrumen penelitian merupakan suatu alat yang dipakai untuk memperoleh data. Jenis angket yang digunakan untuk mendapatkan data dari variabel kreativitas mengajar guru $\left(\mathrm{X}_{1}\right)$, pola asuh orang tua $\left(\mathrm{X}_{2}\right)$, iklim sekolah $\left(\mathrm{X}_{3}\right)$, dan prestasi belajar siswa $(\mathrm{Y})$ adalah angket tertutup. Angket tertutup adalah angket yang disajikan dalam bentuk sedemikian rupa sehingga responden diminta untuk memilih satu jawaban yang sesuai dengan karekteristik dirinya dengan cara memberi tanda silang $(\mathrm{x})$ atau tanda checlist $(\sqrt{ })$ (Ridwan, 2004:99-100).

Validasi instrumen penelitian ini dilakukan dengan rasional apakah butir instrumen menggambarkanindikator dari variabel yang hendak diukur dalam penelitian. Langkah-langkah yang dilakukan dalam validitas isi adalah: (1) membuat kisi-kisi dengan menyusun instrumen berdasarkan indikator yang telah ditentukan untuk konstruk masing-masing variabel; (2) melakukan konsultasi (expert judgement) untuk memerikasa isi instrumen secara sistematis serta mengevaluasi relevansi dengan variabel yang ditentukan, hal ini dilakukan untuk mengetahui sejauh mana instrumen yang digunakan telah mencerminkan keseluruhan aspek yang akan diukur.

Setelah instrumen divalidasi berdasarkan pertimbangan ahli selanjutnya dilakukan validitas konstruk dengan menguji coba instrumen di lapangan, dengan maksud untuk mengetahui validitas dan tingkat reabilitas instrumen. Untuk mengetahui valid tidaknya suatu butir pertanyaan-pertanyaan menggunakan Confirmatory Factor Analysis (CFA). Confirmatory Factor Analysis (CFA)dilakukan untuk menguji indikator-indikator tersebut benarbenar sesuai dengan indikator konstruk dalam teori. Suatu item dalam pertanyaan dikatakan valid apabila nilai faktor loading > 0,05 dan mengelompok pada setiap variabel. Jika faktor loading < 0,05 artinya item tersebut tidak valid, sehingga tidak dapat digunakan untuk penelitian. Dasar pengambilan keputusan untuk uji validitas ini dengan memperhatikan nilai kaiser-meyer-olkin measure of sampling adequacy (KMO MSA. Analisis faktor dapat diteruskan apabila nilai KMO yang dihasilkan
$>0,05$. Jika nilai $\mathrm{KMO}<0,05$ maka analisis faktor yang dihasilkan tidak dapat dilakukan.

Uji reliabilitas digunakan untuk mengukur suatu kuesioner yang mempunyai indikator dari variabel atau konstruk. Suatu kuesioner dinyatakan reliabel atau handal jika jawaban seseorang terhadap pernyataan adalah konsisten atau stabil dari waktu ke waktu (keajegan).

Dalam penelitian ini, suatu konstruk atau variabel dikatakan reliable jika memberikan nilai Cronbanch Alpha> 0,70 (Muijs, 2004:73). Jadi apabila nilai Cronbanch Alpha dari masing-masing variable kreativitas mengajar guru, pola asuh orang tua dan iklim sekolah lebih dari 0,70 maka setiap variabel tersebut dinilai reliabel.

Penelitian ini merupakan penelitian kuantitatif yangmenggunakan statistik. Data akan dianalisis dengan statistik deskriptif dan inferensial. Statistik deskriptif akan menggambarkan data yang telah terkumpul sebagaiman adanya. sedangkan statistik inferensial pada penelitian ini dilakukan dengan menganalisis data sampel yang diambil dari populasi secara random. Analisis yang dilakukan untuk mengetahui tercapainya tujuan penelitian. Adapun analisis yang digunakan adalah analisis deskripsi data, dan analisis regresi ganda.

\section{Hasil Penelitian dan Pembahasan}

Pada bagian ini disajikan deskipsi data hasil penelitian, pengujian persyaratan analisis data penelitian, pengujian hipotesis dan pembahasan hasil penelitian. Deskripsi hasil penelitian merupakan gambaran tentang objek yang diteliti.Berdasarkan hasil penelitian penelitian yang dilakukan maka data yang diperoleh di lapangan, dideskripsikan untuk menguji pengaruh variable bebas dan variabel terikat. Dalam penelitian ini disajikan deskripsi data dari setiap variabel hasilnya dapat dijelaskan sebagai berikut:

Berdasarkan data Prestasi Belajar Siswa yang diperoleh dari 97 siswa yang menjadi sampel menunjukkan bahwa nilai tertinggi yang dicapai oleh siswa sebesar 83 dan nilai terendah sebesar 76. Dari hasil perhitungan statistik diperoleh mean ideal (Mi) sebesar 78,95; median sebesar 78,00; mode sebesar 78; dan standar deviasi ideal (SDi) sebesar 2,468. Distribusi frekuensi variabel data Prestasi Belajar Siswa dapat dilihat pada grafik berikut. 


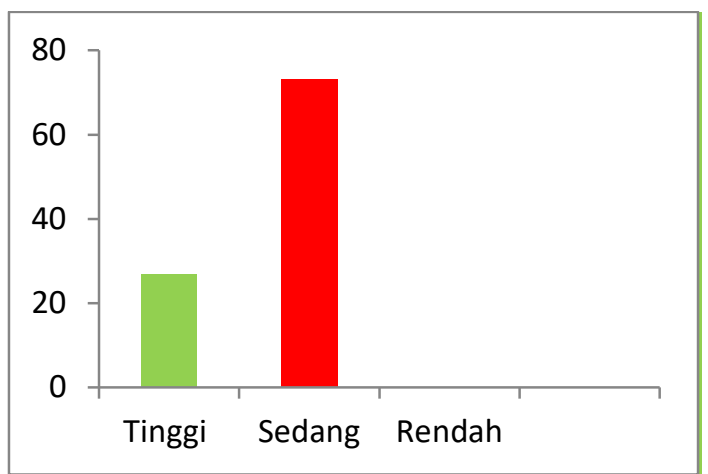

Gambar 1. Distribusi Frekuensi Data Prestasil Belajar

Berdasarkan Gambar 1 tersebut, dapat dideskripsikan bahwa pada variabel Prestasi Belajar Siswa (Y) dari 97 siswa yang menjadi sampel, $26.80 \%$ atau 26 siswa memiliki nilai Prestasi Belajar Siswa kategori tinggi dan $73.20 \%$ atau 73 siswa memiliki nilai kategori sedang. Dari diagram batang dan tabel distribusi frekuensi data Prestasi Belajar Siswa yang diukur menggunakan nilai raport semester ganjil pada mata pelajaran ekonomi menunjukkan bahwa Prestasi Belajar Siswa di SMA Swasta Di Kabupaten Gunungkidul dilihat dari distribusi frekuensi maupun rata-rata termasuk dalam kategori sedang yang ditunjukkan oleh persentase nilai tersebut.

Berdasarkan hasil analisis data menunjukkan bahwa variabel Kreativitas Mengajar Guru $\left(\mathrm{X}_{1}\right)$ diperoleh sekor tertinggi yang dicapai menurut persepsi siswa sebesar 70 , sekor terendah sebesar 49. Dari hasil perhitungan statistik diperoleh mean ideal (Mi) sebesar 61,26 , median sebesar 61,00 mode sebesar 68, dan standar deviasi ideal (SDi) sebesar 5,667. Distribusi frekuensi variabel data Kreativitas Mengajar Guru dapat digambarkan dalam bentuk diagram batang berikut ini:

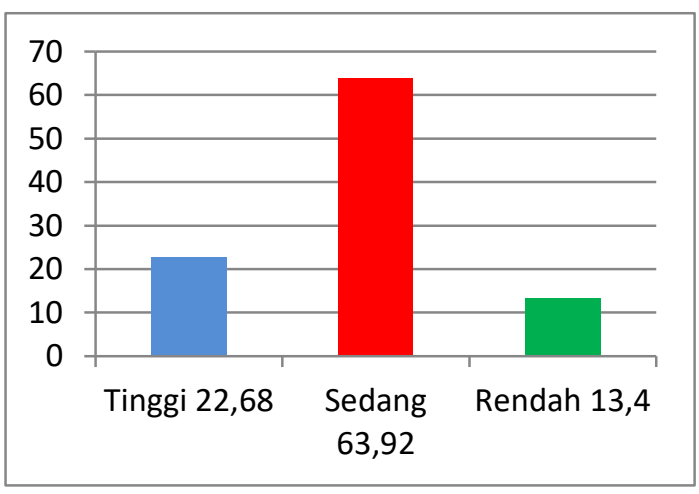

Gambar 2. Distribusi Frekuensi Data Kreativitas Mengajar Guru
Berdasarkan Gambar 2 tersebut, dapat dideskripsikan bahwa variabel Kreativitas Mengajar Guru ( $\left.\mathrm{X}_{1}\right)$ dari 97 siswa yang menjadi sampel, 22,68\% atau 22 siswa mengatakan Kreativitas Mengajar Guru tinggi, 63,92\% atau 62 siswa mengatakan Kreativitas Mengajar Guru sedang, dan 13,40 \% atau 13 siswa mengatakan Kreativitas Mengajar Guru rendah. Dari diagram batang dan tabel distribusi frekuensi data Kreativitas Mengajar Guru menunjukkan, bahwa Kreativitas Mengajar Guru yang diukur menggunakan angket dilihat dari distribusi frekuensi maupun rata-rata termasuk dalam kategori sedang yang ditunjukkan oleh persentase perolehan skor tersebut.

Berdasarkan hasil analisis data menunjukkan bahwa variabel Pola Asuh Orang Tua $\left(\mathrm{X}_{2}\right)$ diperoleh sekor tertinggi yang dicapai oleh siswa berdasarkan angket Pola Asuh Orang Tua sebesar 53, sekor terendah sebesar 40. Dari hasil perhitungan statistik diperoleh mean ideal (Mi) sebesar 46,62, median sebesar 48 , mode sebesar 43 dan standar deviasi ideal (SDi) sebesar 4,552. Distribusi frekuensi variabel data Pola Asuh Orang Tua dapat digambarkan dalam bentuk diagram batang berikut.

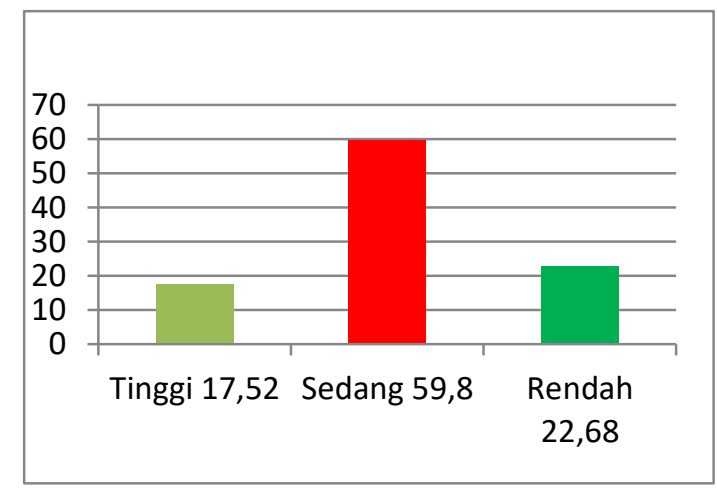

Gambar 3. Distribusi Frekuensi Data Pola Asuh Orang Tua

Berdasarkan Gambar 3, dapat dideskripsikan bahwa variabel Pola Asuh Orang Tua (X2) dari 97 siswa yang menjadi sampel, $17,52 \%$ atau 17 siswa memiliki Pola Asuh Orang Tua kategori tinggi, 59,80\% atau 58 siswa memiliki Pola Asuh Orang Tua kategori sedang, dan $22.68 \%$ atau 22 siswa memiliki Pola Asuh Orang Tua kategori rendah. Dari diagram batang dan tabel distribusi frekuensi data Pola Asuh Orang Tua menunjukkan, bahwa Pola Asuh Orang Tua siswa yang diukur menggunakan angket Pola Asuh Orang Tua di SMA Swasta Di Kabupaten Gunungkidul dili- 
hat dari distribusi frekuensi maupun rata-rata termasuk dalam kategori sedang yang ditunjukkan oleh persentase perolehan skor tersebut.

Berdasarkan hasil analisis data menunjukkan bahwa variabel Iklim Sekolah (X3) diperoleh sekor tertinggi 58 yang dicapai oleh siswa berdasarkan angket Iklim Sekolah, sekor terendah sebesar 44. Dari hasil perhitungan statistik diperoleh mean ideal (Mi) sebesar 50,93, median sebesar 52, mode sebesar 52, dan standar deviasi ideal (SDi) sebesar 4,369. Distribusi frekuensi variabel data Iklim Sekolah (X3) dapat digambarkan dalam bentuk diagram batang berikut.

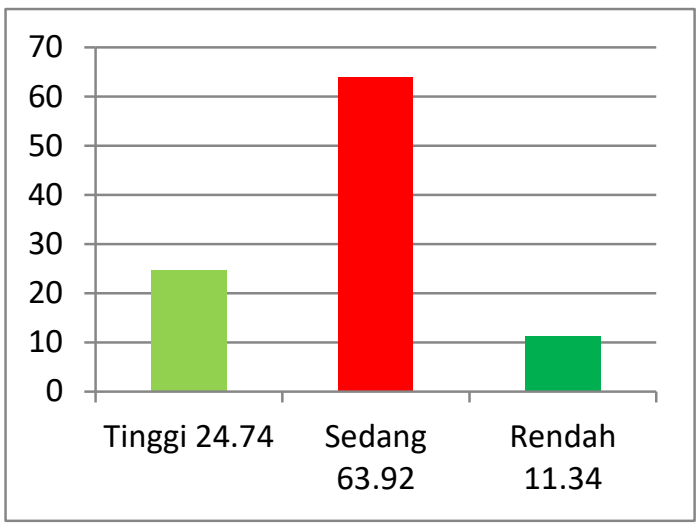

Gambar 4. Distribusi Frekuensi Data Iklim Sekolah

Berdasarkan Gambar 4, dapat dideskripsikan bahwa variabel Iklim Sekolah (X3) dari 97 siswa yang menjadi sampel, $24.74 \%$ atau 24 siswa memiliki Iklim Sekolah kategori tinggi, 63,92\% atau 62 siswa memiliki Iklim Sekolah kategori sedang, dan 11,34\% atau 11 siswa memiliki Iklim Sekolah kategori rendah. Dari diagram batang dan tabel distribusi frekuensi data Iklim Sekolah menunjukkan, bahwa Iklim Sekolah siswa yang diukur menggunakan angket Iklim Sekolah di SMA Swasta Di Kabupaten Gunungkidul dilihat dari distribusi frekuensi maupun rata-rata termasuk dalam kategori sedang yang ditunjukkan oleh persentase perolehan skor tersebut.

Penelitian ini bertujuan untuk mengetahui pengaruh Kreativitas Mengajar Guru, Pola Asuh Orang Tua, dan Iklim Sekolah terhadap Prestasi Belajar Siswa pada mata pelajaran ekonomi di SMA Swasta di Kabupaten Gunungkidul. Berdasarkan data penelitian yang dianalisis, maka dapat dibahas sebagai berikut:
Berdasarkan data statistik dapat dideskripsikan bahwa variabel Kreativitas Mengajar Guru (X1) dari 97 siswa yang menjadi sampel, $22,68 \%$ atau 22 siswa memiliki Kreativitas Mengajar Guru kategori tinggi, 63,92\% atau 62 siswa memiliki Kreativitas Mengajar Guru kategori sedang, 13,40\% atau 13 siswa memiliki Kreativitas Mengajar Guru kategori rendah. Hal ini menunjukkan bahwa Kreativitas Mengajar Guru memberikan kontribusi positif terhadap Prestasi Belajar Siswa.

Hasil uji hipotesis menunjukkan bahwa Kreativitas Mengajar Guru berpengaruh signifikan terhadap Prestasi Belajar Siswa secara parsial dengan koefisien beta 0,041 yang bernilai positif, sedangkan koefisien diterminasi atau besarnya sumbangan pengaruh Kreativitas Mengajar Guru (X3) terhadap Prestasi Belajar Siswa (Y) adalah 0,008 atau 0,8\%. termasuk kategori sangat rendah.

Dalam hal ini kreativitas mengajar guru dalam menyajikan materi pembelajaran, menunjukkan berhasil dalam kriteria kreatif. Hal ini menunjukkan guru mata pelajaran Ekonomi menyajikan materi dengan kreatif. Dengan adanya gambaran ini, guru berupaya lebih kreatif lagi sehingga diharapkan dapat meningkatkan keinginan belajar dari siswa dalam kegiatan belajar mengajar. Hasil dari angket siswa menunjukkan persamaan jawaban yaitu guru dalam kriteria kreatif.

Dalam penelitian ini, secara keseluruhan kreativitas guru dalam menyajikan materi pembelajaran masuk dalam kriteria kreatif dan berada dalam ketercapaian sebesar $99.2 \%$. Guru dalam menyajikan materi memberikan acuan-acuan materi yang akan dipelajari pada siswanya, untuk memberikan gambaran kompetensi yang akan dikuasai dan sering menghubungkan dengan mata pelajaran yang lain. Tujuan yang jelas dan operasional dapat ditetapkan sebagai bahan pelajaran yang harus menjadi sisi kegiatan belajar mengajar. Bahan pengajaran inilah yang diharapkan dapat mewarnai tujuan, mendukung tercapainya tujuan atau tingkah laku yang diharapkan untuk dimiliki siswa.

Dengan demikian, salah satu parameter yang digunakan untuk mengukur tingkat keberhasilan pendidikan adalah Prestasi Belajar Siswa. Untuk mencapai Prestasi Belajar Siswa yang optimal, guru merupakan salah satu faktor penentu berhasil tidaknya suatu pembelajaran. Oleh karena itu, guru harus 
senantiasa mengembangkan diri secara mandiri serta tidak bergantung pada inisiatif kepala sekolah dan supervisor. Sehubungan dengan hasil penelitian tersebut, Guru merupakan faktor utama dalam proses pendidikan. Meskipun fasilitas pendidikannya lengkap dan canggih, namun bila tidak ditunjang oleh keberadaan guru yang berkualitas, mustahil akan menimbulkan proses belajar dan pembelajaran yang maksimal.

Berdasarkan data statistik dapat dideskripsikan bahwa variabel Pola Asuh Orang Tua (X1) dari 97 siswa yang menjadi sampel, 17,52 $\%$ atau 17 siswa memiliki persepsi tentang Pola Asuh Orang Tua tinggi, 59,80 \% atau 58 siswa memiliki persepsi tentang kompetensi guru sedang, dan $22,68 \%$ atau 22 siswa memiliki persepsi tentang Pola Asuh Orang Tua rendah. Hal ini menunjukkan bahwa Pola Asuh Orang Tua memberikan kontribusi positif terhadap Prestasi Belajar Siswa.

Hasil uji hipotesis menunjukkan bahwa Pola Asuh Orang Tua berpengaruh positif dan signifikan terhadap Prestasi Belajar Siswa secara parsial dengan koefisien beta 0,103 yang bernilai positif artinya terjadi hubungan yang searah antara Pola Asuh Orang Tua dengan Prestasi Belajar Siswa, semakin tinggi nilai koefisien regresi Pola Asuh Orang Tua, maka semakin tinggi pula nilai Prestasi Belajar Siswa. sedangkan koefisien diterminasi atau besarnya sumbangan pengaruh Pola Asuh Orang Tua $\left(\mathrm{X}_{1}\right)$ terhadap Prestasi Belajar Siswa (Y) adalah 0,043 atau 4,3\%.

Pada penelitian ini pengaruh Pola Asuh Orang Tua terhadap Prestasi Belajar Siswa sebesar $4,3 \%$. Persentase ini kecil, karena masalah yang terjadi pada Pola Asuh Orang Tua siswa di antaranya: kurangnya waktu keluarga membimbing anak dalam belajar; keluarga belum menyiapkan fasilitas belajar yang memadai; dan keluarga selalu beranggapan bahwa kegiatan belajar di sekolah sudah cukup untuk memenuhi pendidikan anaknya; dan Orang tua siswa terlalu sibuk dengan pekerjaannya yang menyebabkan kurangnya perhatian yang mereka berikan dan cenderung tidak acuh terhadap kegiatan belajar anak, sehingga siswa yang dididik dan dibimbing dalam keluarga yang kurang kasih sayang dan kurang perhatian, maka siswa tersebut akan tumbuh dan berkembang menjadi anak yang nakal dan pemalas. Oleh sebab itu, dukungan kelu- arga sangat berpengaruh terhadap hasil belajar siswa.

Koefisien bernilai positif artinya terjadi hubungan yang searah antara Pola Asuh Orang Tua dengan Prestasi Belajar Siswa, semakin tinggi nilai koefisien Pola Asuh Orang Tua, maka semakin tinggi pula nilai Prestasi Belajar Siswa. Dalam hal ini sesuai dengan pendapat Djamarah (2008, p. 241) mengatakan "keluarga adalah lembaga pendidikan informal (luar sekolah) yang diakui keberadaannya dalam dunia pendidikan". Peranannya tidak kalah penting dari lembaga formal dan non formal. Bahkan sebelum anak didik memasuki sekolah, dia sudah mendapatkan pendidikan dalam keluarga yang bersifat kodrati. Hubungan darah antara kedua orang tua dengan anak menjadikan keluarga sebagai lembaga pendidikan yang alami. Sehingga Pola Asuh Orang Tua sangat mempengaruhi Prestasi Belajar Siswa. Pola Asuh Orang Tua banyak mempengaruhi kegiatan belajar siswa, karena Pola Asuh Orang Tua merupakan tempat dimana siswa melakukan sosialisasi untuk yang pertama kalinya dan lingkungan pertama dalam pembentukan kepribadian kemampuan anak.

Oleh karena itu, partisipasi dukungan orang tua sangat penting bagi siswa dan sudah seharusnya orang tua untuk mendukung pendidikan anak terus-menerus sehingga Prestasi Belajar Siswa yang diperoleh anak akan lebih baik dan optimal, meski beberapa siswa tidak lagi merasakan kehadiran orang tuanya di sekolah ataupun di rumah, karena orang tuannya sudah meninggal, sehingga hanya bersama kerabat bahkan ada siswa yang tidak pernah tahu keberadaan orang tuanya. Oleh karena itu, keterlibatan orang tua juga sangat mendukung keberhasilan anak dalam meraih prestasi ataupun hasil belajar. Dalam hal ini senada denga teori yang dikemukakan oleh Gunarsa (2009, p. 5) mengatakan bahwa Orang Tua merupakan "lingkungan pertama yang mulamula memberikan pengaruh yang mendalam bagi anak". Peran orang tua yang seharusnya adalah sebagai orang pertama dalam meletakkan dasar-dasar pendidikan terhadap anakanaknya. Dengan hal tersebut, kehidupan keluarga terutama peran orang tua merupakan lingkungan pendidikan pertama yang mempunyai peranan penting dalam menentukan dan membina proses perkembangan anak. Tidak menutup kemungkinan bahwa masalah yang dialami siswa di sekolah seperti rendahnya 
prestasi belajar siswa dan berhasil tidaknya proses belajar siswa merupakan akibat atau lanjutan dari situasi Orang Tua yang tidak harmonis dan peran orang tua yang tidak dijalankan dengan baik.

Berdasarkan data statistik dapat dideskripsikan bahwa variabel Iklim Sekolah (X2) dari 97 siswa yang menjadi sampel, $24,74 \%$ atau 24 siswa memiliki Iklim Sekolah kategori tinggi, $63,92 \%$ atau 62 siswa memiliki Iklim Sekolah kategori sedang, 11,34\% atau 11 siswa memiliki Iklim Sekolah kategori rendah. Hal ini menunjukkan bahwa Iklim Sekolah memberikan kontribusi positif terhadap Prestasi Belajar Siswa.

Hasil uji hipotesis menunjukkan bahwa Iklim Sekolah berpengaruh positif dan signifikan terhadap Prestasi Belajar Siswa secara parsial dengan koefisien beta 0,347 yang bernilai positif, sedangkan koefisien diterminasi atau besarnya sumbangan pengaruh Iklim Sekolah $\left(\mathrm{X}_{2}\right)$ terhadap prestasi belajar siswa (Y) adalah 0,376 atau 37,6\%. Dengan demikian dapat juga dikatakan bahwa iklim sekolah akan mempengaruhi aktivitas orang-orang yang ada di sekolah. Hal tersebut juga sesuai pendapat Litwin dan Stringer (Gunbayi, 2007: 1 ), yang menjelaskan iklim sekolah sebagai " $a$ set of measurable properties of the work environment, perceived directly or indirectly by people who live and work in this environment and assumed to influence their motivation and behaviour" (iklim kerja sekolah merupakan kondisi lingkungan kerja yang dirasakan langsung maupun tidak langsung oleh orang-orang yang tinggal dan bekerja di lingkungan tersebut dan diasumsikan dapat berpengaruh terhadap perilaku dan motivasi mereka).

Berdasarkan uraian di atas dapat disimpulkan bahwa hipotesis yang menyatakan terdapat pengaruh yang signifikan antara iklim sekolah terhadap prestasi belajar siswa.

Berdasarkan data statistik dapat dideskripsikan bahwa pada variabel Prestasi Belajar Siswa(Y) dari 97 siswa yang menjadi sampel, $26,80 \%$ atau 26 siswa memiliki nilai Prestasi Belajar Siswa kategori tinggi dan $73,20 \%$ atau 73 siswa memiliki nilai kategori sangat sedang. Hal ini menunjukkan bahwa Prestasi Belajar Siswa berkontribusi positif. Hasil uji hipotesis menunjukkan bahwa Kreativitas Mengajar Guru, Pola Asuh Orang Tua, dan Iklim Sekolah berpengaruh positif dan signifikan terhadap Prestasi Belajar Siswa secara simultan dengan koefisien diterminasi atau besarnya sumbangan pengaruh Kreativitas Mengajar Guru (X1), Pola Asuh Orang Tua (X2), dan Iklim Sekolah(X3) terhadap Prestasi Belajar Siswa (Y) pada mata pelajaran ekonomi di SMA Swasta di Kabupaten Gunungkidul sebesar 0,431 atau 43,1\%. Dan dari hasil uji $\mathrm{F}$ pada taraf signifikan $5 \%$ diketahui nilai probabilitas (p) $0,000<0,05$ yang ditunjukkan pada kolom signifikansi.

Pada penelitian ini pengaruh Kreativitas Mengajar Guru (X1), Pola Asuh Orang Tua (X2), dan Iklim Sekolah(X3) terhadap Prestasi Belajar Siswa pada mata pelajaran ekonomi sebesar 0,431 atau $43,1 \%$ dan sisanya $56,9 \%$ dijelaskan oleh faktor lain di luar model yang diteliti. Hasil penelitian menunjukkan bahwa Kreativitas Mengajar Guru, Pola Asuh Orang Tua, dan iklim Sekolah yang tinggi, maka Prestasi Belajar Siswa juga akan meningkat, dan begitu juga sebaliknya apabila Kreativitas Mengajar Guru, Pola Asuh Orang Tua, dan iklim Sekolah rendah maka Prestasi Belajar Siswa pun menurun.

\section{Simpulan}

Berdasarkan analisis data dan pembahasan dapat ditarik simpulan sebagai berikut.

Berdasarkan distribusi frekuensi data bahwa prestasi belajar siswa termasuk kategori sedang dengan persentase $73,20 \%$, kreativitas mengajar guru kategori sedang dengan persentase $74,23 \%$, Pola Asuh Orang Tua kategori sedang dengan persentase $59,80 \%$, dan iklim sekolah kategori sedang dengan persentase $63,92 \%$. Kreativitas mengajar guru berpengaruh positif dan signifikan terhadap prestasi belajar siswa pada mata pelajaran ekonomi kelas XI IPS di SMA Swasta Kabupaten Gunungkidul dengan koefesien diterminasi $\left(R^{2}\right)$ sebesar 0,08 atau $0,8 \%$ dengan probabilitas $(\mathrm{p}<0,05)$. Pola asuh orang tua berpengaruh positif dan signifikan terhadap prestasi belajar siswa pada mata pelajaran ekonomi kelas XI IPS di SMA Swasta Kabupaten Gunungkidul dengan koefesien diterminasi $\left(R^{2}\right)$ sebesar 0,43 atau $4,3 \%$ dengan probabilitas $(p<0,05)$. Iklim sekolah berpengaruh positif dan signifikan terhadap prestasi belajar siswa pada mata pelajaran ekonomi kelas XI IPS di SMA Swasta Kabupaten Gunungkidul dengan 
koefesien diterminasi $\left(\mathrm{R}^{2}\right)$ sebesar 0,376 atau $37,6 \%$ dengan probabilitas ( $\mathrm{p}<0,05)$. Kreativitas mengajar guru, Pola asuh orang tua, dan iklim sekolah secara bersama-sama memberikan pengaruh positif dan signifikan terhadap prestasi belajar siswa pada mata pelajaran ekonomi kelas XI IPS di SMA Swasta Kabupaten Gunungkiduldengan kontribusi efektif diterminasi $\left(\mathrm{R}^{2}\right)$ sebesar 0,424 atau $42,4 \%$ dengan probabilitas $(\mathrm{p}<0,05)$.

Berdasarkan temuan penelitian tentang adanya pengaruh kreativitas mengajar guru, Pola asuh orang tua, dan iklim sekolah terhadap pretasi belajar Ekonomi, siswa SMA swasta di Kabupaten Gunungkidul membuktikan bahwa pengaruh variable Iklim sekolah paling besar yakni 37,6\% di bandingkan dengan variable kreativitas mengajar Guru dan pola asuh orang tua. Hal ini mengimplikasikan bahwa di dalam prestasi belajar siswa maka aspek yang perlu diperhatikan yaitu iklim sekolah. Sebagai implikasi teoritisnya maka Iklim sekolah dirasakan oleh siswa menjadi bagian tak terpisahkan dari prestasi belajar siswa. Terbentuknya iklim yang kondusif pada sekolah dapat menjadi faktor penunjang bagi peningkatan prestasi. Sebaliknya, sekolah yang kurang menyenangkan, akan mengakibatkan prestasi belajar siswa akan semakin buruk.

Prestasi belajar Ekonomi, siswa SMA Swasta di Kabupaten Gunungkidul di pengaruhi oleh factor-faktor lain, ini terbukti hari hasil temuan penelitian bahwa sumbangan variabel bebas terhadap variable terikat adalah $43,1 \%$ hal ini menandakan bahwa prestasi belajar Ekonomi di pengaruhi oleh factor-faktor lain. Dalam penelitian ini walaupun sangat kecil pengaruh dari kreativitas mengajar guru dan pola asuh orang tua, namun secara tidak langsung kreativitas mengajar guru dan pola asuh orang tua sangat berkontribusi terhadap peningkatan Prestasi belajar siswa.

Dalam penelitian ini diharapkan bagi siswa diharapkan selalu berinteraksi dengan orang-orang yang dapat mendukung dalam belajar dan memanfatkan sarana dan prasarana yang ada sesuai dengan kebutuhan untuk mendapatkan dampak positif bagi peningkatan prestasi belajar, khususnya mata pelajaran Ekonomi, bagi guru kreativitas-kreativitas yang telah dimiliki dapat untuk dipertahankan dan akan lebih baik jika ditingkatkan agar dalam melakukan proses pembelajaran dapat berjalan dengan baik. Cara-cara yang dapat ditempuh oleh guru untuk meningkatkan kreativitas misalnya dengan mengikuti pelatihanpelatihan, berbagi dengan guru yang mempunyai banyak pengalaman mengajar dan tidak menutup diri terhadap dunia informasi tentang media pembelajaran yang dapat digunakan untuk mendukung pelaksanaan pembelajaran agar berjalan lebih efektif, bagi pihak sekolah diharapkan dengan seiring berjalannya waktu untuk lebih melengkapi dan meningkatkan sarana dan prasarana sekolah seperti penambahan peralatan media pembelajaran sehingga tidak terlalu ketinggalan jauh dengan kemajuan teknologi pada saat sekarang ini yang harapannya dapat meningkatkan mutu dari lulusannya, dan bagi peneliti selanjutnya diharapkan dapat melakukan penelitian yang lebih mendalam dan akurat mengenai kreativitas guru baik dalam menyajikan materi, menggunakan metode pembelajaran, dan mengembangkan media pembelajaran dengan cara wawancara dengan responden dan menambah subjek dari penelitian sehingga bentuk kreativitasnya dapat lebih bervariasi dan dapat dijadikan sebagai bahan acuan bagi pihak sekolah dalam menyelenggarakan pendidikan yang akan datang.

\section{Daftar pustaka}

Djamarah, S. B. (2008) Psikologi belajar. Jakarta: Rineka Cipta

Moedjiarto. (2002). Karakteristik sekolah unggul. Surabaya: Duta Graha Pustaka.

Presiden Republik Indonesia. Undang-undang Republik Indonesia Nomor 20 Tahun 2003 tentang Sistem Pendidikan Nasional. 2003

Presiden Republik Indonesia. Undang-undang Republik Indonesia Nomor 14 Tahun 2005 tentang Guru dan Dosen. 2005

Santrock, J.W. (2007). A topical approach to life-span development. New York: McGraw-Hill.

Winkel,. W. S. (1996). Psikologi pendidikan dan evaluasi belajar. Jakarta: PT Gramedia,.

Muijs., D., \& Reynolds, D. (2008). Effective teaching (teori dan aplikasi). Yogyakarta: Pustaka Belajar. 